9. Kurochkin O. V. (2008). Holiday in the context of state-building processes. Bulletin of the Kiev National University of Culture and Arts: Materials of the International Scientific and Practical Conference (p. 185) Kiev: Publishing Center KNUCA [in Ukrainian].

10. Lunacharsky A.V. (1981). About celebrations, stage, circus (p. 186). Moscow: Iskusstvo [in Russian]. Russian].

11. Nazimko A. E. (2007). Event marketing: a guide for customers and performers. Moscow: Vershina [in

12. Petrova I.V. (2011). Cultural practices of the population of such Ukraine: trends and priorities. Culture and modernity 1, 108-113 [in Ukrainian].

13. Rotovsky A. (2006). Systemic PR. Dnepropetrovsk: Balance Business Books [in Ukrainian].

14. Sharoyev I.G. (1986). Directing pop and mass performances. Moscow: Prosveshcheniye [in Russian].

15. Shumovich A. V. (2008). Great Events: Technology and Practice event management. Moscow: Mann, Ivanov and Ferber [in Russian].

Стаття надійшла до редакції 01.06.2018 p.

УДК 7.41-055.2:655.533 "20"

Cheban Victoria

Postgraduate student of the Kyiv National University

of Culture and Arts

ORCID 0000-0001-9632-535X

viktorinaa@ukr.net

\title{
FEMALE IMAGES OF UKRAINIAN WOMEN IN THE WORKS OF ILLUSTRATORS, DESIGNERS OF BOOKS AND MAGAZINES OF THE TWENTIETH CENTURY
}

The purpose of this research is to study the peculiarities and details of the appearance of the girls from the "cover» of the twentieth century, in particular: what was different and what was common in the images of the Ukrainian and foreign masters while working on the cover of books and magazines as well as to determine the functions of women's image in Ukraine and other countries. The methodology of the research is based on the use of cultural, structural, comparative, and analytical methods of study of female images in the works of illustrators, book publishers and magazines of the 20th century. Scientific novelty consists in expanding the notion of female images in the cover pictures of books, illustrations for articles and fashion magazines of the twentieth century. A comparative analysis of the images of Ukrainian girls and foreign women gives us an idea of the different levels of development and self-sufficiency of women of that time. Conclusions. The article examines the stereotypes of women's images and forms a special type (or rather types) of representation of the female body on the covers. It studies "traditional images» of women, the subtleties of appearance of female images on magazine covers and identifies relevant images for drawing portraits on the cover.

Keywords: portrait, image, contrast, female body, female fate, figure, costume, problematics.

meums

Чебан Вікторія Олександрівна, аспірантка Київського національного університету культури і мис-

Жіночі образи в здобутках ілюстраторів, оформлювачів книг, журналів: XX століття

Мета статті - вивчення особливостей і тонкощів зовнішності дівчат «з обкладинки» XX століття, зокрема: чим відрізнялися і що спільного було в зображеннях українських та зарубіжних майстрів у роботі над обкладинкою книг, журналів; визначення того, які саме функції виконує жіночий образ в Україні та інших країнах на обкладинках видань. Методологія дослідження ґрунтується на застосуванні культурологічного, структурного, компаративного, аналітичного методів у дослідженні жіночих образів у здобутках ілюстраторів, офрормлювачів книг, журналів XX сторіччя. Наукова новизна складається в розширенні уявлення про жіночі образи у зображенні на обкладинках книг, ілюстрацій до статей, в журналах XX століття. Порівняльний аналіз образів українських дівчат і зарубіжних дає нам уявлення про різний рівень розвитку та самодостатності жінок того часу. Висновки. Розглянуто і виділено низку характеристик і особливостей у зображенні жіночого образу українських жінок та американських. Сформований особливий тип (типи) репрезентації жіночого тіла дає змогу можна визначити основні типи зображення жінок на картинах, обкладинках та ілюстраціях у книгах в загальних рисах.

Ключові слова: портрет, образ, контраст, жіноче тіло, жіноча доля, фрігура, костюм, проблематика. искусств

Чебан Виктория Александровна, аспирантка Киевского национального университета культуры и налов: XX век

Женские образы украинской женщины в произведениях иллюстраторов, оформителей книг, жур-

Цель статьи - изучение особенностей и тонкостей внешности девушек «с обложки» XX века, в частности: чем отличались и что общего было в изображениях украинских и зарубежных мастеров при работе над обложкой книг, журналов; определение того, какие именно функции выполняет женский образ в Украине и других странах на обложках изданий. Методология исследования основана на применении культурологического, структурного, сравнительного, аналитического методов в исследовании женских образов в произведениях иллюстраторов, оформителей книг, журналов XX столетия. Научная новизна заключается в расширении представления о женских образах при изображении на обложках книг, иллюстрациям к статьям, в журналах XX века. Сравнитель-

(C) Cheban V., 2018 
ный анализ образов украинских девушек и зарубежных дает нам представление о разном уровне развития и самодостаточности женщин того времени. Выводы. Рассмотрены стереотипы женских образов, сформирован особый тип (вернее типы) репрезентации женского тела на обложках. Изучены «традиционные образы» женщины, тонкости изображения женских образов на обложках журналов, определены актуальные образы для нанесения портретов на обложку.

Ключевые слова: портрет, образ, контраст, женское тело, женская судьба, фригура, костюм, проблематика.

Topicality of the research. The different women, fates and images are presented on the pages of fiction and publicistic literature, in painting, sculpture and at a movie screen. The image of real woman or created by imagination is traced in all genres and types of fiction: from folklore to contemporary manifestations of cultural think.

In Ukrainian and foreign folklore, a woman is presented in different icons: of totem, godhead, often in the role of a fighter, nemesis, sister of friend, rival and so on. Her image should be beautiful and ugly, charming and abhorrent. As you know the folklore motives totally influenced the development of literature, art and culture in general.

The research of book envelopes, illustrations of magazines with female images gave so unexpected result: there was a special type of woman body representation in this images. So, there are problems which need a detailed discussion such as visual female images on the magazine and book envelopes, a list of general regularities appropriated for the "existence" of visual list of "female images", compositional schemes, symbolic receptions and colourful building of images, which were used by portrait-painters.

The purpose of the research is to determine what was the main in painting of female image in the book and magazine envelopes for painters; to analyse the features of female portraits of Ukrainian and foreign masters of 20th century; to determine the influence of symbolism for creation of female image and to research the functions of female image in Ukraine and other countries.

Analysis of the last researches and publications. There is a lot of literature about how exactly women were imaged on the pictures, envelopes. Often it deals with images in general and their general characteristic. The researchers pay attention to art studies problems, analysis of art of some painters, but there is no any comprehensive aesthetic and cultural research. The effort of determination of cultural basics of style allows to classify works from this problem: the works of philosophers and cultural scientists, who gave the general understanding of such terms as "femininity", "culture", their phenomenon used in development of categorically-conceptual structure of the research and its main theoretical principles. Here it's should be named the works by D. Lyxachov, O. Shpengler, A. Losyev, V. Asmus, L. Stolovych, M. Ovsyannikov, E. Markaryan, R. Vel'flyn and many others, who showed complexity and polysemy of such terms as "culture", "style", "direction", their correlation with another aesthetic and culturological categories, the process of creation of female images in culture, the researches of the masters of the 20th century.

Henry van de Velde, William Morris, Emile Galle, Max Klinger, Walter Crane and other play the main role among the painters, who made an important influence on formation of theoretical base of the style. The first great and generalizing works dedicated to a woman in generally are written mainly by foreign scientists (for example E. Mihalskiy).

The basic materials of the research. Books with bright illustration, envelopes and different magazines became one of the main issues of value stability of that time. A lot of them are connected with woman and female images. The thematic-value orientation of such publications is a truth and knowledge, science and secular tattle, property and justness, house and design, beauty and health, family and different minorities, hobby and leisure, advertising and production, industry of informative services and sport [7, 16].

\section{ternal world.}

In different times and epochs there was their own ideal of woman according to her outward and in-

Observing the separated groups of 20th century women we can highlight some types of female images similar to those, which are presented on the portraits, pictures and sculptures of Modern and Renaissance. Analysing the works of Ukrainian, English and American painters-portraitists we can highlight the six female types such as the traditional women, the women of Soviet time, Russian feminists, feminists of the west type, non-traditionalists and the escapists [5, 59].

The ideal of woman-worker and woman-citizen appeared in Ukrainian art in twenty-thirties of current century. The family and motherhood are regarded as the "philistinism". The uniformity and homogeneity of love was actively predicated in life as well as in books and illustrations. Everywhere there were imposed the priority of the social interests over the individual, the subordination of love to class principles, the love was perceived more like a common happiness in work. The traditional and usual female features such as softness and ability to empathy were excluded from daily life. The most important female value was the ability to get a victory in socialist competitions. The family for woman is presented only as the additional sphere of realization. Such ideal was kept up to eighties. A woman acquires such features as hyperactivity and even aggressiveness and a man - amorphous, passivity and inability to stand up for oneself and others [2, 101].

If we are talking about the female ideal of 20th century we should say that it was connected with independent woman, who was able to influence social processes, but the contemporary female ideal is long legs, beautiful and expensive things and so on. 
Taking into consideration different female images presented by painters and variety of different key shades, which might be imaged on a picture we can determine some types of female image patterns and female faces.

So, we can determine three stereotypes of female images of that time "which entered the youth female ideals and real female biography". The first of them is the image of "lovely woman with destroyed life", the second - "the evil character, who daringly destroys the all conventionalities of man's world" and the third is the image of "female heroic figure, the main feature of which is the comparison of woman heroism to spiritual man's weakness" [4, 203].

Let's look through the works by famous American painter-illustrator. He was a pilot during the First World War. He created his works for the famous publications and magazines. The beautiful female images abound by their arty, individuality and immediacy. There was a lot of significant changes in 1940. The painter loved to draw women from nature; he had a fine painting of female portraits. From one hand, the aristocratic paleness grew into fashion. From another, the female eyebrow acquired the nature form with gradual narrowing. Except mascara one of the main conditions of stylish make-up of fifty there were elegant wings and eyeshadows in tune to dress or accessories. All of these nice and little things were used by the painter in his works. He studied stylish trends and the last stylish specialties of that time for creation of each of his works. The painter draw female images in corset and bouffant skirt. A shaggy cut also become popular.

Also the painter draws women in underwear with naked body. Heels, corsets, suspenders of fifties were changed to soft bras, knitted tights and boots in the pictures by the famous master. The fifties were characterized by beautiful hard stone busts.

Always the beauty of Ukrainian women impressed the painters, writers and musicians. A lot of artists got the inspiration from such enigmatic beauty and crowned it in their works. The Ukrainian women became the muses for the famous painter-illustrators.

In Ukraine the main part of woman's wear for drawing female image was the "vyshyvanka" (the Ukrainian traditional shirt). It is drawn longer a little bit and includes two parts: lower which is imaged from more close texture than the upper. The young girls were erased only in zoned traditional shirts unlike the older women, who were to have "poneva" (cotton skirt with few pieces of cloth).

The main difference of women head-dress from girl head-dress on the pictures was such thing that they had to cover the head in full. A kerchief was one of the most popular headwear. Frequently they wore the "kybalka" (some hoop twisted on the hair).

Traditionally young girls were imaged in the wreath from live and artificial flowers and designed with tapes. Among other types of female head-dresses there were popular tapes, kerchiefs, pieces of silver and golden brocade, metal wire with different pendants or flowers, colorized cardboard circle and so on. All of this accessories did not cover the head and leaving the braid, the main pride of Ukrainian girls, open.

Usually the women did not have any accessories on the illustrations of daily life, but going to the church or for some holiday they designed their neck with many different beads. Frequently they defined the social status of women exactly by such accessories.

Therefore, having analysed the pictures and images of women of 20th century I got absolutely unexpected result: there was formed the special type of presenting of female body and we can determine the main types of drawing of women on the pictures, envelopes and book illustrations on the such common traits as:

1. "Portraits": female images, which remind the photos on a passport. Usually these are little photos, situated by 2-3 on one page, or in line by $4-6$ along the page's perimeter. The photos are not always signed. Often only surname is signed. Also the author's surname is missing.

The types of image named the "portraits", are just the statement of outward, so it fixes only the outside similarity. Frequently the face expressions are so monotonous. The situation of spontaneity is absolutely excluded, the calm preparedness testifies about it. I think that women were warned previously about the drawing of their portrait for the publication.

2. "The multi-headed portraits": it's the special type of images, specific photo-collage that consists with a list of twin photos of women cut out on the upper contour. There can be different female heads situated in one or more lines, so one photo above another. Frequently (at the beginning of the thirties) such collages are printed without any signs. From the middle of the thirties appear the signs under the whole photo.

3 . The images have exactly ornamental character (as they are without any signs). But then some signs gradually appear. The uniformity and similarity are reinforced by abundant retouch, that cause not only to similarity of female faces, but also create an impression of pictures with not real people, but some strange pictures.

4. "The woman-machine": the photos of ordinary format, which present the woman at working on the machine, tractor, in the field and so on. In some cases the person is not so clear. Sometimes she is imaged from the back. There are two types of signing: specialty, surname (sometimes with name), "at working on/in...", or just: "Turner/milker at working" ( without any additional specifications), or "Fitter of the plant (at working)".

To such type we can relate "woman-diagram", photo-collage that presents woman among the different graphs and diagrams. Usually it is a big collage (one and a half page with figures and comments). 
5. "The machine": such pictures present a sort of continuation of corporeality outside, it is not "people near the machine" or "people working on the machine" but it is "people-machine". The human body is undivided from the "mechanism", like he is incomplete and insignificant without it. Such pictures are characterized by absence of any signs as they show some labour process, but not some people. A photographer sees the machine, and people just serve it. So it causes the fuzziness in drawing of people.

6. "The masses": the crowded pictures of different size, which present some meetings, demonstrations, teaching, where some people practically have not any differences. Usually there is not any information, who is on the picture, there is only what is happening and where [3, 24].

The event is so important for the painter and the book, that some people are not significant, it is important only that there are so many people. Usually people are so similar on the pictures. It should to say that it clearly presents unity and unanimity of participants imaged on the picture.

Conclusion. The reasons of changes in drawing of female images by Ukrainian and foreign painters of 20th century were changes, which happened in common European culture. The main portrait quality is still faithfulness of the person characteristics, but on the other hand there is the established fashion of image. Therefore, a portrait becomes a portrait of person's role more than of a woman herself. However, such contradiction of role and essence makes the portraits more psychological.

Studying the portraits of Ukrainian, American and English portrait painters we can say that there are six female types such as traditional women, women of Soviet time, Russian feminists, feminists of the west type, non-traditionalists and escapists. Also we define three types of female images in drawing of female nature of that time which "entered the girl ideals and real female biographies": "of lovely woman with destroyed feelings and life", "of the evil character that destroys all conventionalities of man's world", and "the third typical literary-social image of woman-heroine".

Having analysed the works of Ukrainian and foreign masters we studied and defined the list of characteristics and features of female image of Ukrainian and American women.

There was formed the special type of presenting female body, and we can determine the main types of woman's image on the pictures, envelopes and book illustrations on the common traits.

\section{References}

1. Bjelova, O. Ju. (1997). Arts history. Moscow: "Akvarium" publishing house.

2. Benjamin. (1996). Art work in epoch of his technical reproducibility: Selected essay. Moscow.

3. Gholubovych, K. (1985). Enjoyment with space: new image. New literary review, 39, 373-385.

4. Ghudova, M. Ju. (2010). Female glossy magazines: chronotope of imaginary daily life. Monograph. Yekaterinburgh: Publishing house of Ural University.

5. Molj, A. (1986). Art futurology. About role of kitsch and copy in social and aesthetic development. In V. Ju. Borev \& A. Kovalenko (Eds.), Culture and mass communication. Moscow.

6. Ryklin, M. (1992). Terrorologiki. Moscow: Tartu.

7. Syksus, E. (1995). Woman - body - text. Art magazine, 6, 32-35.

Стаття надійшла до редакції 25.07.2018 p. 